\title{
PENGARUH PEMBERIAN DOSIS PUPUK NPK DAN JENIS PUPUK HAYATI TERHADAP PERTUMBUHAN DAN PRODUKSI TANAMAN BAWANG MERAH (Allium ascalonicum L.)
}

\author{
Effect of NPK Fertilizer Dosage and Bio-fertilizer Types on Growth and Yield \\ of Shallot (Allium ascalonicum L.)
}

\author{
Kus Hendarto ${ }^{1}$, Setyo Widagdo ${ }^{1}$, Sri Ramadiana ${ }^{1}$, Fitria Sita Meliana ${ }^{2}$ \\ ${ }^{1}$ Jurusan Agroteknologi, Fakultas Pertanian, Universitas Lampung \\ ${ }^{2}$ Jurusan Agronomi dan Hortikultura, Fakultas Pertanian, Universitas Lampung \\ Jl. Sumantri Brojonegoro No 1 Gedung Meneng, Bandar Lampung 35145 \\ *E-mail korespondensi: kus.hendarto@fp.unila.ac.id
}

\begin{abstract}
ABSTRAK
Bawang merah (Allium ascalonicum L.) merupakan salah satu komoditas sayuran unggulan yang digunakan sebagai bumbu penyedap makanan dan obat tradisional. Penelitian ini bertujuan untuk mengetahui pengaruh pemberian berbagai dosis pupuk NPK dan jenis pupuk hayati terhadap pertumbuhan dan produksi tanaman bawang merah. Penelitian ini menggunakan Rancangan Acak Kelompok (RAK) yang disusun secara faktorial $(4 \times 2)$. Faktor pertama adalah dosis pupuk NPK yang terdiri dari empat taraf yaitu: $\mathrm{N}_{0}=0 \%$ (tanpa pupuk NPK), $\mathrm{N}_{1}=50 \%\left(25 \mathrm{~g} / \mathrm{m}^{2}\right), \mathrm{N}_{2}=100 \%\left(50 \mathrm{~g} / \mathrm{m}^{2}\right)$, dan $\mathrm{N}_{3}=150 \%\left(75 \mathrm{~g} / \mathrm{m}^{2}\right)$. Faktor kedua adalah jenis pupuk hayati yang terdiri dari dua taraf yaitu: $\mathrm{H}_{1}=$ Pupuk Grikulan plus dan $\mathrm{H}_{2}=$ EM4. Hasil penelitian menujukkan bahwa perlakuan dosis pupuk NPK sampai dengan dosis $75 \mathrm{~g} / \mathrm{m}^{2}$ memberikan hasil terbaik pada pertumbuhan dan perkembangan tanaman yaitu meliputi jumlah daun, tinggi tanaman, bobot umbi segar per tanaman, bobot umbi kering angin per tanaman, dan bobot umbi kering angin per $\mathrm{m}^{2}$. Pertumbuhan dan perkembangan tanaman bawang merah dengan aplikasi pupuk hayati Grikulan plus lebih baik dibandingkan dengan pupuk hayati EM4. Perlakuan dosis pupuk NPK $150 \%$ atau setara dengan $75 \mathrm{~g} / \mathrm{m}^{2}$ disertai dengan aplikasi pupuk Grikulan plus menghasilkan produksi tertinggi yaitu bobot umbi kering angin per $\mathrm{m}^{2}$ mencapai 1674,33 $\mathrm{g}$ atau setara dengan 11,72 ton/ha.
\end{abstract}

Kata kunci: Bawang merah, EM4, Grikulan plus, Pupuk NPK

\begin{abstract}
Shallots (Allium ascalonicum L.) is one of the leading vegetable commodities used as food seasoning and traditional medicine. This study aims to see the effect of providing various doses of NPK fertilizer and types of biological fertilizers on the growth and production of shallot plants. This study used a randomized block design (RAK) arranged in a factorial (4 $x$ 2). The first factor is the NPK fertilizer dosage which consists of four levels, namely: $N_{0}=0 \%$ (without NPK fertilizer), $N_{l}=50 \%\left(25 \mathrm{~g} / \mathrm{m}^{2}\right)$, $N_{2}=100 \%\left(50 \mathrm{~g} / \mathrm{m}^{2}\right)$, and $N_{3}=150 \%\left(75 \mathrm{~g} / \mathrm{m}^{2}\right)$. The second factor is the type of biological fertilizer which consists of two levels, namely: $H_{1}=$ Grikulan plus fertilizer and $H_{2}=E M 4$. The results showed that the NPK fertilizer dosage treatment up to a dose of $75 \mathrm{~g} / \mathrm{m}^{2}$ gave the best results on plant growth and development, including the number of leaves, plant height, fresh tuber weight per plant, wind dry tuber weight per plant, and wind dry tuber weight per $m^{2}$. The growth and development of shallot plants with the application of Grikulan biological fertilizers were better than those of EM4 biological fertilizers. Treatment of NPK fertilizer dosage of $150 \%$ or equivalent to $75 \mathrm{~g} / \mathrm{m}^{2}$ supplemented with the application of Grikulan plus fertilizer results in higher production, namely the weight of dry tubers per $m^{2}$ reaching $1674.33 \mathrm{~g}$ or equivalent to 11.72 tonnes/ha.
\end{abstract}

Key words : EM4, Grikulan plus, shallots,NPK, yield 


\section{PENDAHULUAN}

Bawang merah (Allium ascalonicum L.) merupakan salah satu komoditas sayuran unggulan yang digunakan sebagai bumbu penyedap makanan dan obat tradisional. Industri pengolahan makanan yang diusahakan oleh masyarakat meningkat setiap tahunnya sehingga kebutuhan bawang merah di dalam negeri juga semakin meningkat. Hal ini yang menjadikan komoditas bawang merah memiliki nilai ekonomi yang tinggi (Sumarni dan Hidayat, 2005).

Kebutuhan bawang merah di Indonesia dari tahun ke tahun untuk konsumsi dan bibit dalam negeri mengalami peningkatan sebesar 5\%. Penghasil utama bawang merah pada 2017 secara berturut-turut yaitu Provinsi Jawa Tengah, Jawa Timur, Nusa Tenggara Barat, Jawa Barat, Sulawesi Selatan, dan Sumatera Barat. Pada tahun 2019 produksi bawang merah di Provinsi Lampung hanya mencapai 2104,8 ton dengan luas panen sebesar 262 ha yaitu setara dengan 8,03 ton/ha (Badan Pusat Statistik, 2019).

Produktivitas bawang merah nasional tahun 2015 mengalami penurunan sebesar 0,39\% dibandingkan dengan tahun 2014 . Pada tahun 2014 produktivitas nasional bawang merah mencapai 10,14 ton/ha, sedangkan pada tahun 2015 hanya mencapai 10,06 ton/ha. Penurunan produksi bawang merah disebabkan oleh faktor kesuburan tanah (Badan Pusat Statistik, 2016).

Salah satu upaya untuk meningkatkan kandungan unsur hara dan kesuburan tanah untuk meningkatkan produktivitas bawang merah yaitu dengan cara pemupukan. Pupuk NPK Mutiara mengandung tiga unsur hara yang sangat dibutuhkan oleh tanaman, yaitu $\mathrm{N}$, $\mathrm{P}$, dan $\mathrm{K}$ dengan perbandingan unsur setara yaitu 16:16:16. Masing-masing unsur hara tersebut dibutuhkan tanaman bawang merah dalam proses pertumbuhan vegetatif dan generatif tanaman.

Pemupukan anorganik dalam jangka panjang menyebabkan kandungan bahan organik menurun, kerusakan struktur tanah, dan pencemaran lingkungan (Isnaini, 2006). Pupuk hayati merupakan suatu alternatif untuk memanfaatkan mikroorganisme tertentu dalam jumlah banyak untuk meningkatkan kesuburan tanah, menyediakan hara, membantu pertumbuhan tanaman dengan cara menambat unsur $\mathrm{N}$ yang cukup besar dari udara, dan dapat melarutkan unsur $\mathrm{P}$ dan $\mathrm{K}$ dalam keadaan yang tidak dapat diserap oleh tanaman menjadi dapat diserap oleh tanaman (Hasibuan, 2006). Sumarni dkk. (2012) menyatakan bahwa penggunaan pupuk NPK dengan dosis $600 \mathrm{~kg} / \mathrm{ha}$ memberikan pengaruh terbaik pada produksi bawang merah.

Pupuk hayati digunakan untuk meningkatkan efisiensi serapan hara yang terkandung dalam pupuk NPK. Oleh karena itu, dengan banyaknya manfaat yang terkandung dalam pupuk NPK ditambah dengan pupuk hayati maka dilakukan penelitian ini dengan tujuan untuk mengetahui pengaruh interaksi pupuk NPK dan jenis pupuk hayati yang sesuai yang dapat meningkatkan pertumbuhan dan produksi tanaman bawang merah.

\section{METODE PENELITIAN}

Penelitian ini dilaksanakan di Desa Sukabanjar, Kecamatan Gedong Tataan, Kabupaten Pesawaran, Lampung. Bahan yang digunakan adalah bibit bawang merah varietas Bima Brebes, pupuk NPK Mutiara, pupuk kandang kambing dan pupuk hayati (Grikulan plus dan EM4).

\section{Rancangan Percobaan}

Penelitian ini menggunakan Rancangan Acak Kelompok (RAK) yang disusun secara faktorial (4×2) dengan tiga ulangan. Pengelompokkan berdasarkan diameter umbi bibit yang akan ditanam. Umbi berukuran besar memiliki diameter lebih dari $1,8 \mathrm{~cm}$ pada kelompok pertama, umbi berukuran sedang memiliki diameter 1,5 sampai dengan $1,8 \mathrm{~cm}$ pada kelompok 
kedua, dan umbi berukuran kecil yaitu dengan diameter kurang dari atau sama dengan 1,5 cm pada kelompok ketiga.

Faktor pertama yaitu dosis pupuk majemuk NPK Mutiara (N) dan faktor kedua yaitu aplikasi pupuk hayati $(\mathrm{H})$. Faktor pertama terdiri dari empat taraf yaitu $\mathrm{N}_{0}=$ $0 \%$ (tanpa pupuk NPK), $\mathrm{N}_{1}=50 \%\left(25 \mathrm{~g} / \mathrm{m}^{2}\right)$, $\mathrm{N}_{2}=100 \%\left(50 \mathrm{~g} / \mathrm{m}^{2}\right)$, dan $\mathrm{N}_{3}=150 \%(75$ $\mathrm{g} / \mathrm{m}^{2}$ ). Faktor kedua terdiri dari dua taraf yaitu $\mathrm{H}_{1}=$ Pupuk Grikulan plus dan $\mathrm{H}_{2}=$ EM4. Grikulan plus mengandung sejumlah bakteri yaitu Azotobacter sp., Azospirillum sp., Pseudomonas sp., dan Bacillus sp., EM4 mengandung mikroorganisme fermentasi dan sintetik yang terdiri dari bakteri asam laktat (Lactobacillus sp.), bakteri fotosintetik (Rhodopseudomons sp.), jamur fermentasi (Saccharomyces sp.), dan Actinomycete.

Terdapat 8 kombinasi perlakuan yang diulang sebanyak 3 kali sehingga diperoleh 24 satuan percobaan. Terdapat 48 tanaman dalam satu satuan percobaan dan 6 tanaman dipilih secara acak sebagai tanaman sampel. Homogenitas ragam data yang diperoleh diuji menggunakan Uji Barlett, sedangkan Uji Additivitas dilakukan dengan Uji Tukey. Jika data dinyatakan homogen dan bersifat menambah maka data dianalisis dengan analisis ragam dan dilakukan pengujian perbedaan nilai tengah dengan Uji Beda Nyata Terkecil (BNT) pada taraf 5\%.

\section{Pelaksanaan Penelitian}

Penyiapan lahan diawali dengan membersihkan gulma dan sisa tanaman yang ditanami sebelumnya. Selanjutnya dilakukan pengolahan tanah. Pengolahan tanah dilakukan secara mekanik menggunakan cangkul. Tanah dibentuk bedengan berukuran $1 \times 12 \mathrm{~m}$ dengan tinggi $25 \mathrm{~cm}$ sebanyak 3 bedengan. Satu bedengan terdapat 8 satuan percobaan yang ditentukan menggunakan sistem pengacakan. Setiap petak satuan percobaan berukuran $1 \times 2 \mathrm{~m}$. Selanjutnya masing-masing bedengan tersebut diberikan kapur dolomit sebanyak $10 \mathrm{~kg}$ dan pupuk kandang kambing sebanyak
6,5 kg. Pupuk tersebut ditebarkan diatas bedengan secara merata di permukaan tanah kemudian ditutup kembali dengan tanah. Jarak tanam bawang merah yaitu $0,15 \times 0,15$ $\mathrm{m}$. Selanjutnya dilakukan pemasangan mulsa plastik perak untuk mengurangi tumbuhnya gulma.

Bibit ditanam dengan cara menancapkan satu siung bawang merah ke tanah hingga setengah bagian umbi masuk ke dalam tanah. Umbi ditanam sesuai dengan ukuran umbi, umbi yang berukuran besar pada kelompok 1, berukuran sedang umbi berukuran sedang pada kelompok 2, dan umbi berukuran kecil pada kelompok 3 .

Pengambilan sampel tanaman bawang merah dilakukan dengan sistem pengacakan. Masing-masing petak terdiri dari 48 tanaman dan 6 tanaman sebagai sampel, sehingga total sampel pada ketiga ulangan yaitu 144 tanaman. Pemeliharaan rutin yang dilakukan meliputi kegiatan penyiraman yaitu dengan menggunakan gembor atau dengan cara pemberian air hingga setengah bagian bedengan terisi air yaitu menggunakan sistem "leb".

Umbi bawang merah dipanen setelah sebagian daun tanaman mulai rebah $60 \%$ 90\% yaitu pada umur 65 hari setelah tanam. Panen dilakukan dengan cara mencabut seluruh bagian tanaman dengan hati-hati agar umbi tidak rusak maupun tertinggal. Umbi yang telah dipanen kemudian dibersihkan, diikat, dan dikeringkan.

Peubah yang diamati meliputi tinggi tanaman, jumlah daun, bobot umbi segar per tanaman, bobot umbi kering angin per tanaman, dan bobot umbi kering angin per $\mathrm{m}^{2}$. Tinggi tanaman diukur dari permukaan tanah hingga ujung daun terpanjang. Pengukuran tinggi tanaman dan jumlah daun dilakukan pada saat tanaman berumur $1 \mathrm{mst}$ sampai 7 mst. Bobot umbi segar diperoleh pada saat panen dengan cara menimbang umbi setelah panen agar umbi masih dalam keadaan segar. Umbi yang ditimbang dibersihkan dari akar, daun, dan tanah yang melekat pada umbi. Bobot kering angin umbi diperoleh dari penimbangan umbi 
setelah dikeringanginkan selama satu minggu.

\section{Aplikasi Perlakuan}

Aplikasi pupuk NPK Mutiara dilakukan sebanyak tiga kali yaitu pada 1 minggu setelah tanam (mst), 3 mst, dan 5 mst. Aplikasi pupuk majemuk NPK diberikan dengan dosis yaitu $\mathrm{N}_{0}$ tanpa pupuk NPK, $\mathrm{N}_{1}$ sebanyak $25 \mathrm{~g} / \mathrm{m}^{2}, \mathrm{~N}_{2}$ sebanyak 50 $\mathrm{g} / \mathrm{m}^{2}$, dan $\mathrm{N}_{3}$ sebanyak $75 \mathrm{~g} / \mathrm{m}^{2}$ (Tabel 1). Pupuk NPK ditaburkan ke permukaan tanah di sekililing tanaman. Aplikasi pupuk hayati yaitu pupuk Grikulan plus dan EM4 diberikan pada tanah dengan konsentrasi 20 $\mathrm{ml} / \mathrm{l}$ per $\mathrm{m}^{2}$. Aplikasi pupuk hayati Grikulan plus dan EM4 dilakukan sebanyak tiga kali yaitu $1 \mathrm{mst}, 3 \mathrm{mst}$, dan $5 \mathrm{mst}$ dengan cara menyiramkan larutan pupuk hayati ke seluruh permukaan tanah di sekililing tanaman. Larutan pupuk hayati diberikan sebanyak 41,7 ml/tanaman.

Tabel 1. Takaran pemberian dosis pupuk NPK pada setiap perlakuan

\begin{tabular}{ccccc}
\hline \multirow{2}{*}{ No } & $\begin{array}{c}\text { Dosis NPK } \\
\left(\mathrm{g} / \mathrm{m}^{2}\right)\end{array}$ & \multicolumn{3}{c}{ Umur Tanaman } \\
\cline { 3 - 5 } & $0\left(\mathrm{~N}_{0}\right)$ & 0 & 0 & 0 \\
\hline 1. & $25 s t$ & $3 \mathrm{mst}$ & $5 \mathrm{mst}$ \\
2. & $25\left(\mathrm{~N}_{1}\right)$ & 10 & 10 & 5 \\
3. & $50\left(\mathrm{~N}_{2}\right)$ & 20 & 20 & 10 \\
4. & $75\left(\mathrm{~N}_{3}\right)$ & 30 & 30 & 15 \\
\hline
\end{tabular}

\section{HASIL DAN PEMBAHASAN}

Hasil penelitian menunjukkan bahwa dosis pupuk NPK, jenis pupuk hayati, dan interaksi dosis pupuk NPK dengan jenis pupuk hayati berpengaruh nyata terhadap beberapa variabel pengamatan. Hasil rekapitulasi analisis ragam pada variabel pengamatan disajikan pada Tabel 2.

\section{Tinggi Tanaman}

Perlakuan berbagai dosis pupuk NPK berpengaruh nyata pada tinggi tanaman 6 mst. Namun perlakuan jenis pupuk hayati dan interaksi pupuk NPK dengan jenis pupuk hayati tidak berpengaruh nyata pada tinggi tanaman 6 mst. Perlakuan $\mathrm{N}_{3}$ yaitu NPK dengan dosis $75 \mathrm{~g} / \mathrm{m}^{2}$ menghasilkan tinggi tanaman tertinggi yaitu $38,48 \mathrm{~cm}$ dibandingkan dengan perlakuan lainnya (Tabel 3). Perlakuan tanpa menggunakan pupuk NPK menghasilkan tinggi tanaman paling rendah yaitu $30,62 \mathrm{~cm}$ namun tidak berbeda nyata dengan perlakuan $\mathrm{N}_{1}$ (NPK 25 $\mathrm{g} / \mathrm{m}^{2}$ ), dan $\mathrm{N}_{2}$ (NPK $50 \mathrm{~g} / \mathrm{m}^{2}$ ).

Tabel 2. Rekapitulasi pengaruh dosis pupuk NPK, jenis pupuk hayati, dan interaksinya pada variabel pengamatan

\begin{tabular}{lccc}
\hline \multirow{2}{*}{$\begin{array}{c}\text { Variabel } \\
\text { Pengamatan }\end{array}$} & \multicolumn{2}{c}{ Perlakuan } & \\
\cline { 2 - 3 } & $\begin{array}{c}\text { Dosis } \\
\text { NPK }\end{array}$ & $\begin{array}{c}\text { Jenis } \\
\text { Pupuk } \\
\text { Hayati }\end{array}$ & Interaksi \\
\hline $\begin{array}{l}\text { Tinggi Tanaman } \\
(\mathrm{cm})\end{array}$ & $* *$ & tn & tn \\
Jumlah Daun & $* *$ & tn & tn \\
$\begin{array}{l}\text { Bobot Umbi } \\
\text { Segar }(\mathrm{g})\end{array}$ & $* *$ & $* *$ & $*$ \\
$\begin{array}{l}\text { Bobot Umbi } \\
\text { Kering Angin }(\mathrm{g})\end{array}$ & $* *$ & $* *$ & $*$ \\
$\begin{array}{l}\text { Bobot Umbi } \\
\text { Kering Angin per } \\
\mathrm{m}^{2}\left(\mathrm{~g} / \mathrm{m}^{2}\right)\end{array}$ & $* *$ & $* *$ & $*$ \\
\hline
\end{tabular}

Keterangan:

$\begin{array}{ll}\text { tn } & =\text { tidak berbeda nyata } \\ * & =\text { berbeda nyata pada } \alpha 5 \% \\ * * & =\text { berbeda nyata pada } \alpha 1 \%\end{array}$

Tabel 3. Pengaruh pemberian dosis pupuk NPK pada tinggi tanaman bawang merah

\begin{tabular}{cc}
\hline Dosis NPK & $\begin{array}{c}\text { Tinggi Tanaman } \\
\text { Minggu ke-6 }\end{array}$ \\
\hline $0\left(\mathrm{~N}_{0}\right)$ & $30,62 \mathrm{c}$ \\
$25\left(\mathrm{~N}_{1}\right)$ & $33,34 \mathrm{bc}$ \\
$50\left(\mathrm{~N}_{2}\right)$ & $35,45 \mathrm{~b}$ \\
$75\left(\mathrm{~N}_{3}\right)$ & $38,48 \mathrm{a}$ \\
\hline BNT 5\% & 2,91 \\
\hline
\end{tabular}

Keterangan: Angka yang diikuti huruf yang sama tidak berbeda nyata pada taraf 5\% 


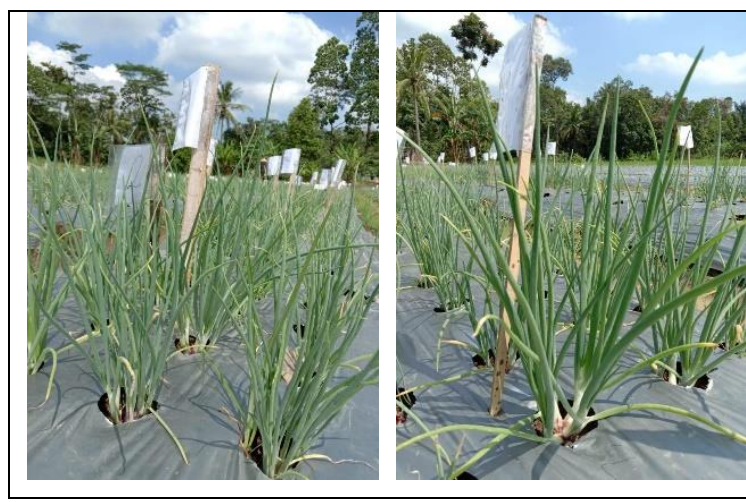

Gambar 1. Pertumbuhan tanaman

\section{Jumlah Daun}

Hasil penelitian menunjukkan perlakuan jenis pupuk hayati dan interaksi pupuk NPK dan jenis pupuk hayati tidak berpengaruh nyata terhadap jumlah daun pada 6 mst. Namun, perlakuan berbagai dosis pupuk NPK berpengaruh nyata terhadap jumlah daun tanaman bawang merah. Perlakuan dosis pupuk NPK $75 \mathrm{~g} / \mathrm{m}^{2}$ $\left(\mathrm{N}_{3}\right)$ menghasilkan jumlah daun yang lebih banyak dibandingkan dengan perlakuan $\mathrm{N}_{1}$ dan $\mathrm{N}_{0}$ (Tabel 4).

Tabel 4. Pengaruh dosis pupuk NPK terhadap jumlah daun per tanaman

\begin{tabular}{cc}
\hline Dosis NPK & Jumlah Daun \\
\hline $0\left(\mathrm{~N}_{0}\right)$ & $26,22 \mathrm{c}$ \\
$25\left(\mathrm{~N}_{1}\right)$ & $28,44 \mathrm{bc}$ \\
$50\left(\mathrm{~N}_{2}\right)$ & $31,56 \mathrm{ab}$ \\
$75\left(\mathrm{~N}_{3}\right)$ & $36,22 \mathrm{a}$ \\
\hline BNT 5\% & 4,84 \\
\hline
\end{tabular}

Keterangan: Angka yang diikuti huruf yang sama tidak berbeda nyata pada taraf 5\%

\section{Bobot Umbi Segar}

Peubah bobot umbi segar bawang merah menunjukkan adanya interaksi antara aplikasi pupuk NPK dan pupuk hayati. Perlakuan NPK dengan dosis $25 \mathrm{~g} / \mathrm{m}^{2}\left(\mathrm{~N}_{1}\right)$, dosis $75 \mathrm{~g} / \mathrm{m}^{2}\left(\mathrm{~N}_{3}\right)$, dan tanpa pupuk NPK dengan aplikasi pupuk hayati Grikulan plus $\left(\mathrm{H}_{1}\right)$ dan EM4 $\left(\mathrm{H}_{2}\right)$ tidak menunjukkan perbedaan yang nyata. Namun aplikasi pupuk NPK dengan dosis $50 \mathrm{~g} / \mathrm{m}^{2}\left(\mathrm{~N}_{2}\right)$ dengan aplikasi pupuk hayati Grikulan plus $\left(\mathrm{H}_{1}\right)$ menghasilkan bobot umbi segar per tanaman nyata lebih berat dibandingkan dengan pupuk hayati EM4 (Tabel 5).

Pada perlakuan pupuk hayati EM4, perlakuan NPK $75 \mathrm{~g} / \mathrm{m}^{2}\left(\mathrm{~N}_{3}\right)$ menghasilkan bobot umbi segar lebih tinggi dibandingkan dengan perlakuan lainnya. Pada perlakuan pupuk hayati Grikulan plus, perlakuan $\mathrm{N}_{3}$ menghasilkan bobot umbi segar lebih tinggi dibandingkan dengan perlakuan $\mathrm{N}_{0}$ dan $\mathrm{N}_{1}$ namun tidak berbeda nyata dengan perlakuan $\mathrm{N}_{2}$.

Tabel 5. Pengaruh dosis pupuk NPK dan jenis pupuk hayati terhadap bobot umbi segar per tanaman $(\mathrm{g})$

\begin{tabular}{ccc}
\hline \multirow{2}{*}{ Dosis NPK } & \multicolumn{2}{c}{ Jenis Pupuk Hayati } \\
\cline { 2 - 3 } & $\begin{array}{c}\text { Grikulan } \\
\text { plus }\left(\mathrm{H}_{1}\right)\end{array}$ & EM4 $\left(\mathrm{H}_{2}\right)$ \\
\hline $0\left(\mathrm{~N}_{0}\right)$ & $40,34 \mathrm{~A}$ & $35,79 \mathrm{~A}$ \\
& $\mathrm{c}$ & $\mathrm{b}$ \\
$25\left(\mathrm{~N}_{1}\right)$ & $50,31 \mathrm{~A}$ & $45,20 \mathrm{~A}$ \\
& $\mathrm{~b}$ & $\mathrm{~b}$ \\
$50\left(\mathrm{~N}_{2}\right)$ & $62,66 \mathrm{~A}$ & $43,22 \mathrm{~B}$ \\
& $\mathrm{a}$ & $\mathrm{b}$ \\
$75\left(\mathrm{~N}_{3}\right)$ & $63,45 \mathrm{~A}$ & $58,67 \mathrm{~A}$ \\
& $\mathrm{a}$ & $\mathrm{a}$ \\
\hline BNT & & 7,52 \\
\hline
\end{tabular}

Keterangan: Angka sebaris pada yang diikuti huruf besar yang sama dan angka sekolom yang diikuti huruf kecil yang sama menunjukkan tidak berbeda nyata pada taraf $5 \%$.

\section{Bobot Umbi Kering Angin per Tanaman}

Bobot umbi kering angin bawang merah dipengaruhi oleh interaksi antara aplikasi pupuk NPK dan pupuk hayati. Hasil uji lanjut (Tabel 6) menunjukkan bahwa perlakuan NPK dengan dosis $25 \mathrm{~g} / \mathrm{m}^{2}\left(\mathrm{~N}_{1}\right)$, dosis $75 \mathrm{~g} / \mathrm{m}^{2}\left(\mathrm{~N}_{3}\right)$, dan tanpa pupuk NPK dengan aplikasi pupuk hayati Grikulan plus $\left(\mathrm{H}_{1}\right)$ dan EM4 $\left(\mathrm{H}_{2}\right)$ tidak berpengaruh nyata. Namun, aplikasi pupuk NPK dengan dosis $50 \mathrm{~g} / \mathrm{m}^{2}\left(\mathrm{~N}_{2}\right)$ dengan aplikasi pupuk hayati 
Grikulan plus $\left(\mathrm{H}_{1}\right)$ menghasilkan bobot umbi kering angin per tanaman lebih berat yaitu 59,11 g dibandingkan dengan perlakuan aplikasi pupuk hayati EM4 $\left(\mathrm{H}_{2}\right)$ yaitu 40,50 g per tanaman.

Pada perlakuan pupuk hayati EM4, perlakuan NPK $75 \mathrm{~g} / \mathrm{m}^{2}\left(\mathrm{~N}_{3}\right)$ menghasilkan bobot umbi kering angin per tanaman lebih tinggi dibandingkan dengan perlakuan lainnya. Pada perlakuan pupuk hayati Grikulan plus, perlakuan $\mathrm{N}_{3}$ menghasilkan bobot umbi kering angin per tanaman lebih tinggi dibandingkan dengan perlakuan $\mathrm{N}_{0}$ dan $\mathrm{N}_{1}$ namun tidak berbeda nyata dengan perlakuan $\mathrm{N}_{2}$.

Tabel 6. Pengaruh pemberian dosis pupuk NPK dan jenis pupuk hayati terhadap bobot umbi kering angin per tanaman $(\mathrm{g})$

\begin{tabular}{ccc}
\hline \multirow{2}{*}{ Dosis NPK } & \multicolumn{2}{c}{ Jenis Pupuk Hayati } \\
\cline { 2 - 3 } & $\begin{array}{c}\text { Grikulan } \\
\text { plus }\left(\mathrm{H}_{1}\right)\end{array}$ & EM4 $\left(\mathrm{H}_{2}\right)$ \\
\hline $0\left(\mathrm{~N}_{0}\right)$ & $37,56 \mathrm{~A}$ & $32,78 \mathrm{~A}$ \\
& $\mathrm{c}$ & $\mathrm{c}$ \\
$25\left(\mathrm{~N}_{1}\right)$ & $46,94 \mathrm{~A}$ & $41,56 \mathrm{~A}$ \\
& $\mathrm{~b}$ & $\mathrm{~b}$ \\
$50\left(\mathrm{~N}_{2}\right)$ & $59,11 \mathrm{~A}$ & $40,50 \mathrm{~B}$ \\
& $\mathrm{a}$ & $\mathrm{b}$ \\
$75\left(\mathrm{~N}_{3}\right)$ & $60,22 \mathrm{~A}$ & $54,22 \mathrm{~A}$ \\
& $\mathrm{a}$ & $\mathrm{a}$ \\
\hline BNT & & 7,62 \\
\hline
\end{tabular}

Keterangan: Angka sebaris pada yang diikuti huruf besar yang sama dan angka sekolom yang diikuti huruf kecil yang sama menunjukkan tidak berbeda nyata pada taraf $5 \%$.

\section{Bobot Umbi Kering Angin per $m^{2}$}

Bobot umbi kering angin bawang merah dipengaruhi oleh interaksi antara aplikasi pupuk NPK dan pupuk hayati. Berdasarkan hasil uji lanjut (Tabel 7), perlakuan pupuk hayati Grikulan plus $\left(\mathrm{H}_{1}\right)$ pada pupuk NPK dengan dosis $50 \mathrm{~g} / \mathrm{m}^{2}\left(\mathrm{~N}_{2}\right)$, dan dosis $75 \mathrm{~g} / \mathrm{m}^{2}\left(\mathrm{~N}_{3}\right)$ menghasilkan bobot umbi yang lebih berat dibandingkan dengan perlakuan pupuk hayati EM4 $\left(\mathrm{H}_{2}\right)$. Namun, pada perlakuan NPK dosis $25 \mathrm{~g} / \mathrm{m}^{2}\left(\mathrm{~N}_{0}\right)$ dan tanpa pupuk NPK dengan aplikasi pupuk hayati Grikulan plus $\left(\mathrm{H}_{1}\right)$ dan EM4 $\left(\mathrm{H}_{2}\right)$ tidak berbeda nyata. Perlakuan pemberian pupuk NPK dengan dosis $75 \mathrm{~g} / \mathrm{m}^{2}\left(\mathrm{~N}_{3}\right)$ menghasilkan bobot umbi per $\mathrm{m}^{2}$ lebih berat dibandingkan dengan perlakuan lainnya. Perlakuan tanpa pupuk NPK menghasilkan bobot umbi per $\mathrm{m}^{2}$ lebih ringan dibandingkan dengan perlakuan lainnya. Namun perlakuan $\mathrm{N}_{2}$ (NPK $50 \mathrm{~g} / \mathrm{m}^{2}$ ) dan $\mathrm{N}_{1}$ (NPK $25 \mathrm{~g} / \mathrm{m}^{2}$ ) pada aplikasi pupuk hayati EM4 menghasilkan bobot umbi per $\mathrm{m}^{2}$ yang tidak berbeda nyata. Pada perlakuan pupuk hayati EM4, perlakuan NPK $75 \mathrm{~g} / \mathrm{m}^{2}\left(\mathrm{~N}_{3}\right)$ menghasilkan bobot umbi kering angin per $\mathrm{m}^{2}$ lebih tinggi dibandingkan dengan perlakuan lainnya. Pada perlakuan pupuk hayati Grikulan plus, perlakuan $\mathrm{N}_{3}$ menghasilkan bobot umbi kering angina per $\mathrm{m}^{2}$ tertinggi dibandingkan dengan perlakuan lainnya.

Tabel 7. Pengaruh dosis pupuk NPK dan jenis pupuk hayati terhadap bobot umbi kering angin per $\mathrm{m}^{2}\left(\mathrm{~g} / \mathrm{m}^{2}\right)$

\begin{tabular}{ccc}
\hline \multirow{2}{*}{ Dosis NPK } & \multicolumn{2}{c}{ Jenis Pupuk Hayati } \\
\cline { 2 - 3 } & $\begin{array}{c}\text { Grikulan } \\
\text { plus }\left(\mathrm{H}_{1}\right)\end{array}$ & EM4 $\left(\mathrm{H}_{2}\right)$ \\
\hline $0\left(\mathrm{~N}_{0}\right)$ & $901,40 \mathrm{~A}$ & $786,67 \mathrm{~A}$ \\
& $\mathrm{~d}$ & $\mathrm{c}$ \\
& $1126,67 \mathrm{~A}$ & $997,33 \mathrm{~A}$ \\
$25\left(\mathrm{~N}_{1}\right)$ & $\mathrm{c}$ & $\mathrm{b}$ \\
& $1418,67 \mathrm{~A}$ & $972,00 \mathrm{~B}$ \\
$50\left(\mathrm{~N}_{2}\right)$ & $\mathrm{b}$ & $\mathrm{b}$ \\
& $1674,33 \mathrm{~A}$ & $1301,33 \mathrm{~B}$ \\
$75\left(\mathrm{~N}_{3}\right)$ & $\mathrm{a}$ & $\mathrm{a}$ \\
\hline BNT & & 167,73 \\
\hline
\end{tabular}

Keterangan: Angka sebaris pada yang diikuti huruf besar yang sama dan angka sekolom yang diikuti huruf kecil yang sama menunjukkan tidak berbeda nyata pada taraf $5 \%$. 


\section{Pembahasan}

Hasil penelitian menunjukkan bahwa pemberian pupuk NPK dengan dosis $75 \mathrm{~g} / \mathrm{m}^{2}$ $\left(\mathrm{N}_{3}\right)$ memberikan hasil terbaik pada seluruh parameter pertumbuhan tanaman. Hal ini diduga karena unsur $\mathrm{N}$, $\mathrm{P}$, dan $\mathrm{K}$ yang diberikan pada perlakuan $\mathrm{N}_{3}$ yaitu NPK dengan dosis $75 \mathrm{~g} / \mathrm{m}^{2}$ mampu meningkatkan pertumbuhan vegetatif tanaman sehingga pertumbuhan generatif tanaman bawang merah optimal.

Pemberian pupuk NPK dengan dosis $75 \mathrm{~g} / \mathrm{m}^{2}$ diduga telah mampu meningkatkan ketersediaan unsur $\mathrm{N}$ pada tanah. Meningkatnya ketersediaan unsur $\mathrm{N}$ pada tanah mampu meningkatkan pertumbuhan vegetatif tanaman bawang merah. Hal ini didukung oleh Napitulu dan Winarto (2010) bahwa unsur $\mathrm{N}$ dapat meningkatkan sintesis protein dan pembentukan klorofil. Ketersediaan unsur $\mathrm{N}$ dalam jumlah yang cukup dapat melancarkan proses metabolisme tanaman yang akan mempengaruhi pertumbuhan organ-organ tanaman seperti batang, daun, dan akar.

Dianita dan Abdullah (2011) juga menyatakan bahwa ketersediaan unsur $\mathrm{N}$ yang cukup pada pertumbuhan vegetatif tanaman mampu membentuk asam amino menjadi protein. Protein yang terbentuk digunakan dalam proses fotosintesis kemudian akan membentuk bagian-bagian vegetatif dengan cepat. Jaringan meristem akan mengalami pembelahan sel, pembesaran, dan pemanjangan sel-sel baru sehingga pertumbuhan tanaman berlangsung baik. Deden dan Umiyati (2020) juga menyatakan bahwa tanaman bawang merah akan aktif membelah membentuk anakan setelah fase pertumbuhan vegetatif yang telah dicapai.

Pemberian pupuk NPK dengan dosis $75 \mathrm{~g} / \mathrm{m}^{2} \quad\left(\mathrm{~N}_{3}\right)$ menghasilkan bobot umbi segar per tanaman, bobot kering angin, dan bobot umbi kering angin per $\mathrm{m}^{2}$ yang lebih berat dibandingkan dengan perlakuan lainnya. Kalium mempunyai peranan penting sebagai aktivator enzim dalam metabolisme tanaman, kalium berperan dalam sintesis protein dan karbohidrat, serta meningkatkan translokasi fotosintat ke seluruh bagian tanaman.pada fase generatif. Bassiony (2006) menyatakan bahwa unsur K berperan dalam meningkatkan bobot kering bawang merah. Unsur P merupakan salah satu unsur penyusun Adenosin Trifosfat (ATP) dalam tanaman yang berperan penting dalam fotosintesis dan perkembangan akar (Ginting et al., 2006). Semakin baik hasil fotosintesis maka semakin besar pula umbi yang terbentuk (Siagian et al., 2019).

Aplikasi pupuk hayati berpengaruh nyata terhadap parameter bobot umbi segar per tanaman, bobot umbi kering angin, tanaman, dan bobot umbi kering angin per $\mathrm{m}^{2}$. Mikroba dan zat pengatur tumbuh yang terkandung dalam pupuk hayati diduga mampu meningkatkan pertumbuhan dan perkembangan tanaman. Hal ini didukung oleh Husna (2014) yang menyatakan bahwa pupuk hayati yang mengandung Azotobacter sp., dan Azospirillum sp. dapat menghasilkan zat-zat pengatur tumbuh yang dapat mempercepat pertumbuhan tanaman. Hormon-hormon pertumbuhan yang dihasilkan oleh mikroba pada pupuk hayati yaitu hormon auksin, sitokinin, dan giberelin. Pupuk hayati juga mengkolonisasi perakaran tanaman yang mempengaruhi perpanjangan akar tanaman sehingga penyerapan nutrisi dapat berlangsung dengan baik (Rana et al., 2018). Hal ini dapat menyebabkan proses pembentukan umbi menjadi lebih baik, dan berpengaruh terhadap kualitas umbi yang dihasilkan.

Perlakuan NPK dengan dosis $75 \mathrm{~g} / \mathrm{m}^{2}$ $\left(\mathrm{N}_{3}\right)$ disertai dengan pupuk hayati Grikulan plus $\left(\mathrm{H}_{1}\right)$ memberikan hasil terbaik yaitu bobot umbi segar, bobot umbi kering angin, dan bobot umbi per petak. Hal ini diduga bahwa unsur $\mathrm{P}$ dan $\mathrm{K}$, serta peran bakteri yang terdapat dalam pupuk hayati Grikulan plus seperti mikroba pelarut fosfat dapat bekerja dengan baik. Hal tersebut didukung oleh Siagian et al. (2012) yang menyatakan bahwa fosfor berfungsi dalam perbaikan 
kandungan karbohidrat, dan pembentukan akar serta meningkatkan hasil umbi-umbian. Pupuk hayati Grikulan plus yang mengandung bakteri Pseudomonas sp., berfungsi sebagai pelarut fosfat (P) memproduksi antibiotik pelindung penyakit, merangsang pembentukan hormon ZPT auksin, sitokinin, dan giberelin, serta menghambat etilen. Bakteri Pseudomonas sp., akan menghasilkan asam organik yang akan membentuk senyawa-senyawa komplek dengan ion $\mathrm{Fe}$ dan Al sehingga unsur fosfat akan dapat tersedia bagi tanaman (Dermiyati, 2015).

Berdasarkan hasil penelitian, pemberian pupuk hayati Grikulan plus memberikan hasil yang lebih baik dibandingkan dengan EM4 pada seluruh parameter pertumbuhan generatif tanaman. Hal tersebut diduga bahwa pada kedua jenis pupuk hayati tersebut mengandung beberapa mikroorganisme yang berbeda. Effective Mikroorganism (EM4) belum memberikan hasil yang optimal pada parameter pertumbuhan generatif tanaman disebabkan karena EM4 lebih berfungsi sebagai dekomposer. Dengan demikian dapat diartikan bahwa EM4 hanya berperan sebagai bahan pembenah tanah bagi pengomposan bahan organik. Hal tersebut didukung oleh Djuarnani et al. (2005) yang menyatakan bahwa EM4 merupakan bioaktivator yang mengandung banyak mikroorganisme pemecah bahan organiksalah satunya yaitu bakteri asam laktat. Fitria et al. (2017) juga menyatakan bahwa pada parameter bobot umbi per tanaman maupun bobot umbi kering matahari bahwa perlakuan yang menggunakan kombinasi pupuk hayati EM4 dan pupuk tanpa kombinasi memberikan hasil yang lebih rendah.

Grikulan plus yang diaplikasikan pada tanah mengandung sejumlah bakteri yaitu Azotobacter sp., Azospirillum sp., Pseudomonas sp., Bacillus sp., dan mikroba pelarut fosfat (Gunarto, 2015). Azospirillum sp. dan Azotobacter sp. merupakan mikroba yang berfungsi sebagai mikroba yang dapat menambat $\mathrm{N}$ dari udara dan menghasilkan hormon pertumbuhan seperti auksin, sitokinin, dan giberelin (Dermiyati, 2015). Unsur $\mathrm{N}$ tersedia dengan adanya bantuan oleh bakteri Azospririllum sp. yang memiliki enzim nitrogenase yang dapat mengubah $\mathrm{N}_{2}$ dari hasil fiksasi menjadi $\mathrm{NH}_{4}{ }^{+}$(Marlina et al., 2018). Nitrogen bebas yang difiksasi secara hayati akan membantu peningkatan fotosintesis selanjutnya fotosintat dalam bentuk karbohidrat akan ditranslokasikan keseluruh jaringan tanaman dan selanjutnya akan digunakan untuk menunjang pertumbuhan dan perkembangan organ tanaman (Gunarto, 2015). Dengan adanya bakteri tersebut mampu meningkatkan ketersediaan unsur $\mathrm{N}$ di dalam tanah dan hormon yang dihasilkan dapat merangsang pertumbuhan tanaman bawang merah, meningkatkan penyerapan unsur hara sebagai penunjang pertumbuhan dan produksi tanaman bawang merah.

Pengaplikasian pupuk NPK yang dikombinasikan dengan pupuk hayati Grikulan plus kombinasi pupuk NPK dan pupuk hayati sangat menguntungkan dalam proses budidaya tanaman. Pupuk hayati yang diaplikasikan pada tanah secara terusmenerus dan berkesinambungan akan memberikan manfaat dalam pemakaian jangka panjang dan memberikan keuntungan dalam budidaya tanaman. Pupuk hayati bersifat multi fungsi yang mampu memperbaiki sifat fisik, kimia, dan biologi tanah. Mustari (2004) juga menyebutkan bahwa penggunaan pupuk anorganik dengan pupuk hayati dapat digunakan untuk meningkatkan produksi dan produktivitas tanaman.

Hasil penelitian menunjukkan bahwa pertumbuhan tanaman dan hasil produksi bawang merah terbaik yaitu pada dosis NPK sebesar $75 \mathrm{~g} / \mathrm{m}^{2}$ atau setara dengan $600 \mathrm{~kg}$ NPK/ha disertai dengan aplikasi pupuk hayati Grikulan plus. Hasil produksi bawang merah dengan perlakuan tersebut memberikan hasil bobot umbi kering angin per $\mathrm{m}^{2}$ terbaik yaitu mencapai $1674,33 \mathrm{~g}$ atau setara dengan 11,72 ton/ha. Produksi 
tersebut telah mencapai potensi produktivitas tanaman bawang merah varietas Bima Brebes yaitu 9,9 ton/ha dan telah mencapai potensi produktivitas bawang merah Provinsi Lampung yaitu 8,03 ton/ha. Hal tersebut menunjukkan bahwa pemberian pupuk NPK dengan pupuk hayati dapat mengefisiensikan penggunaan pupuk NPK dalam pembentukkan dan perkembangan umbi. Pupuk hayati juga berperan dalam memperbaiki kesuburan tanah sehingga perakaran tanaman dapat dengan baik menyerap unsur hara di dalam tanah. Dengan demikian pertumbuhan dan produksi tanaman bawang merah semakin meningkat.

\section{KESIMPULAN}

Dari hasil penelitian ini dapat disimpulkan bahwa:

1. Pemberian pupuk NPK dosis $75 \mathrm{~g} / \mathrm{m}^{2}$ memberikan hasil terbaik pada pertumbuhan dan perkembangan tanaman yaitu meliputi jumlah daun, tinggi tanaman, bobot umbi segar per tanaman, bobot umbi kering angin per tanaman, dan bobot umbi kering angin per $\mathrm{m}^{2}$;

2. Pemberian pupuk hayati Grikulan plus memberikan hasil lebih baik pada seluruh parameter pertumbuhan tanaman bawang merah dibandingkan dengan penggunaan pupuk hayati EM4;

3. Pengaruh pupuk NPK bergantung pada jenis pupuk hayati yang digunakan, dosis pupuk NPK $75 \mathrm{~g} / \mathrm{m}^{2}$ dan pupuk hayati Grikulan plus menghasilkan produksi yang lebih tinggi yaitu bobot umbi kering angin per $\mathrm{m}^{2}$ mencapai $1674,33 \mathrm{~g}$ atau setara dengan 11,72 ton/ha.

\section{DAFTAR PUSTAKA}

Badan Pusat Statistik. 2016. Produksi Bawang Merah Provinsi Tahun 2011-2015. http://www.pertanian.go.id. Diakses pada 15 Agustus 2020.
Badan Pusat Statistik. 2017. Statistik Tanaman Sayuran dan Buah-buahan Semusim. https://www.bps.go.id. Diakses pada 15 Agustus 2020.

Bassiony, A.M.2006. Effect of Potassium Fertilization on Growth, Yield, and Quality of Onion Plants. J. Appl. Scie. Res. 2(10): 780-785.

Dermiyati. 2015. Sistem Pertanian Organik Berkelanjutan. Penerbit Plantaxia. Yogyakarta. $121 \mathrm{hlm}$.

Dianita, R dan Abdullah. 2011. Effect of Nitrogen Fertilizer on Growth Characteristics and Productivity of Creeping Forage Plants for Tree Pasture Integreted System. Jurnal of Agricultural Science and Technology. 3(1): 1118-1121.

Djuarnani, N., Kristian., dan S.S. Budi. 2005. Cara Cepat Membuat Kompos. Agro Media Pustaka. Depok. 74 hlm.

Eviati dan Sulaiman. 2009. Analisis Kimia Tanah, Tanaman, Air, dan Pupuk. Balai Penelitian Tanah. Jawa Barat. 143 hlm.

Firmansyah, I., L. Khaririyatun., dan Yufdy. 2015. Pertumbuhan dan Hasil Bawang Merah dengan Aplikasi Pupuk Organik dan Pupuk Hayati pada Tanah Alluvial. J. Hort. 25 (2):133-141.

Fitria, E.L., W.S.D. Yamika., dan M. Santosa. 2017. Pengaruh Biourin, EM4 dan Pupuk terhadap Pertumbuhan dan Hasil Bawang Merah (Allium Ascalonicum L.) pada Kondisi Ternaungi. Jurnal Produksi Tanaman. 5 (3): 475-483.

Gunarto, L. 2015. Bio Max Grow. Kementerian Pertanian Republik Indonesia. Jakarta.

Gunawan, D. 2010. Budidaya Bawang Merah. Agritek. Jakarta. http://pustakadeptan.go.id. Diakses pada 14 Agustus 2020.

Hardjowigeno, S. 2003. Ilmu Tanah. Akademika Pressindo. Bogor. Hlm 66-70.

Hasibuan, B.E. 2004. Pupuk dan Pemupukan. Universitas Sumatera Utara. Medan. Jurnal Online Agroekoteknologi. 3(3) : 1219 - 1225. Diakses pada 16 Juni 2020. 
Hasibuan, B.E. 2006. Pupuk dan Pemupukan. Universitas Sumatera Utara. Medan. 74 hlm.

Hidayat, A. dan R. Rosliani 1996. Pengaruh Pemupukan N, P, dan K pada Pertumbuhan dan Produksi Bawang Merah Kultivar Sumenep. J. Hort. 5(5):39-43.

Husna. 2013. Pemanfaatan Pupuk Hayati (Pseudomonas flourescens) untuk Meningkatkan Efisiensi Pemupukan pada Tanaman Tomat. Skripsi. Fakultas Pertanian Universitas Lampung.

Isnaini, M. 2006. Pertanian Organik. Penerbit Kreasi Wacana. Yogyakarta.

Marlina, N., N. Amir., dan B. Palmasari. Pemanfaatan Berbagai Jenis Pupuk Organik Hayati terhadap Produksi Bawang Merah (Allium ascalonicum L.) di Tanah Pasang Surut Tipe Luapan C Asal Banyuurip. Jurnal Lahan Suboptimal. 7 (1): 74-79.

Musnamar. 2003. Pupuk Organik : Cair dan Padat, Pembuatan, Aplikasi. Penebar Swadaya. Jakarta.

Napitupulu, D. dan L. Winarto. 2010. Pengaruh Pemberian Pupuk $\mathrm{N}$ dan $\mathrm{K}$ terhadap Pertumbuhan dan Produksi Bawang Merah. J. Hort. 20(1): 27-35.

Rana, R., M.R.. Setiawati, dan Suriadikusumah. 2018. Pengaruh Pupuk Hayati dan Anorganik terhadap Populasi Bakteri Pelarut Fosfat, Kandungan Fosfat (P), dan Hasil Tomat Hidroponik. Jurnal Biodjati. 3(1): 15-22.

Rosliani, R. dan Hilman. 2002. Pengaruh Pupuk Urea Hayati dan Pupuk Organik Penambat Nitrogen terhadap Pertumbuhan dan Hasil Bawang Merah. J. Hort. 12(1): 17-27.
Setiawati, M.R., E.T. Sofyan, dan Z. Mutaqin. 2016. Pengaruh Pupuk Hayati Padat terhadap Serapan N dan P Tanaman, Komponen Hasil dan Hasil Padi Sawah (Oryza Sativa L.). Jurnal Agroekotek. 8 (2): 120-130.

Siagian, T.V., F. Hidayat, dan S.Y. Tyasmoro. 2019. Pengaruh Pemberian Dosis Pupuk NPK dan Hayati terhadap Pertumbuhan dan Hasil Tanaman Bawang Merah (Allium ascalonicum L.). Jurnal Produksi Tanaman. 7 (11): 2151-2160.

Simanungkalit, R.D.M., Saraswati R., Hastuti R.D., dan Husen E. 2006. Pupuk Organik dan Pupuk Hayati. Balai Besar Penelitian dan Pengembangan Sumberdaya Lahan Pertanian. Jawa Barat. 113 hlm.

Sumarni, N. dan R. Rosliani. 2002. Pengaruh Kerapatan Tanaman dan Konsentrasi Larutan NPK 15-15-15 terhadap Produksi Umbi Bawang Merah Mini dalam Kultur Agregat Hidroponik. J. Hort. 12(1):11-16.

Sumarni, N. dan Hidayat. 2005. Budidaya Bawang Merah. Balai Penelitian Tanaman Sayuran. Jakarta. $31 \mathrm{hlm}$.

Sumarni, N., R. Rosliani, dan R.S. Basuki. 2012. Respons Pertumbuhan, Hasil Umbi, dan Serapan Hara NPK Tanaman Bawang Merah terhadap Berbagai Dosis Pemupukan NPK pada Tanah Alluvial. $J$. Hort. 22(4): 366-375.

Sumiati, E. dan O. S. Gunawan. 2007. Aplikasi Pupuk Hayati Mikoriza untuk Meningkatkan Efisiensi Serapan Unsur Hara NPK serta Pengaruhnya terhadap Hasil dan Kualitas Umbi Bawang Merah. J. Hort. 17(1): 34-42. 